Beyond Philology No. 15/1, 2018

ISSN 1732-1220, eISSN 2451-1498

\title{
The importance of formal grammar skills: Reflections on Polish students learning Norwegian
}

\author{
JENS HAUGAN
}

Received 12.02.2018, received in revised form 25.06.2018, accepted 29.06.2018.

\begin{abstract}
Norwegian and Scandinavian languages in general have grown quite popular among Polish students in recent years and more and more Polish universities are trying to offer Bachelor's and even Master's programmes in a Scandinavian language.

Based on experience as a teacher of a Norwegian grammar course at the University of Szczecin and as a teacher of grammar at the Inland Norway University of Applied Sciences which in 2016/2017 hosted around twenty Erasmus+ students from Szczecin, some of the challenges for Polish students of academic Norwegian will be reflected upon, as well as some of the challenges for a teacher of Norwegian who has very little knowledge of Polish. The main purpose of this paper will be to argue for the importance of grammar skills in language education and especially in language teacher education. This study is a contribution to the Educational Role of Language network.
\end{abstract}

\section{Keywords}

foreign language teaching, foreign language learning, language didactics, grammar skills, teacher education, educational role of language 


\title{
Znaczenie znajomości gramatyki formalnej: Refleksje na temat polskich studentów uczących się języka norweskiego
}

\begin{abstract}
Abstrakt
Język norweskie i inne języki skandynawskie stały się w ostatnich latach bardzo popularne wśród polskich studentów, a coraz więcej polskich uczelni stara się oferować programy licencjackie, a nawet magisterskie w językach skandynawskich.

Bazując na swoim doświadczeniu nauczyciela kursu $z$ gramatyki języka norweskiego na Uniwersytecie Szczecińskim oraz nauczyciela gramatyki na Inland Norway University of Applied Sciences, gdzie w roku akademickim 2016/2017 goszczono około dwudziestu studentów programu Erasmus+ ze Szczecina, opisuje niektóre wyzwania stojace przed polskimi studentami, jak również wyzwania stojace przed nauczycielem języka norweskiego mającego bardzo mała znajomość języka polskiego. Głównym celem tego artykułu jest zwrócenie uwagi na znaczenie umiejętności gramatycznych w edukacji językowej, a zwłaszcza w edukacji nauczycieli języków obcych. Niniejsze opracowanie stanowi wkład w sieć Educational Role of Language.
\end{abstract}

\section{Słowa kluczowe}

nauczanie języków obcych, nauka języków obcych, dydaktyka językowa, gramatyka, edukacja nauczycieli, edukacyjna rola języka

\section{Introduction}

This paper was presented at the Second International Conference "Educational Role of Language, Social and Cultural Determinants" at the University of Gdansk in June 2017 (ERL 2, 2017). The Division of Research on Childhood and School at the Department of Education organises an international network of researchers (ERL Network, 2017) that collaborates in order to answer a variety of questions related to the educational role of language (ERL). The key objective of the second 
ERL conference and the ERL network was to study the educational role of language from the perspective of different nations and continents.

The present contribution to the ERL network has its background in the situation that Norwegian and Scandinavian languages in general have grown quite popular among Polish students in recent years, with an increasing number of Polish universities offering undergraduate and even graduate programmes in a Scandinavian language. The University of Szczecin (2013) and some private universities in Warsaw and Krakow are the most recent providers of academic studies in Norwegian, while the study programmes at the universities of Gdansk and Poznan are well established in that field.

During 2016/2017, I taught Norwegian grammar courses at the University of Szczecin. I have also been a teacher of Norwegian grammar at Inland Norway University of Applied Sciences where we in 2016/2017 hosted around twenty Erasmus+ students from Szczecin. In the present paper, "grammar" is used as a general term covering the grammatical disciplines of phonology, morphology, syntax, semantics and pragmatics.

Based on the experiences with teaching Norwegian grammar on an academic level to foreign students, some of the challenges for Polish students of academic Norwegian will be reflected upon, as well as some of the challenges for a teacher of Norwegian who has very little knowledge of Polish. The main question in this paper is as simple as asking what a language teacher actually needs to know. In the "real world" of language teaching, many students, and also many teachers, seem to have a preference for the literature and cultural part of the language they are studying or teaching. The main goal of asking about professional competences is to draw attention to the formal education of language teachers and to raise awareness regarding the need for formal linguistic skills in language teacher education. In the next section, we will look at some more questions related to the goals of the ERL network. 


\section{Methodological and theoretical foundations: The Educational Role of Language (ERL) network}

The ERL network was established in 2016, following an initiative from the Division of Research on Childhood and School, Department of Education at the University of Gdansk. This network consists of researchers from many fields, not only pedagogy, language teaching and linguistics, but also psychology, philosophy and other disciplines that may have a broader interest in the role of language. The main goal of the ERL network is to bring together academics whose work and interests combine language and educational science. Following the rationale of the "linguistic turn", network members jointly study how language shapes our understanding of the world and how people function in it. There are various projects with different perspectives on language beliefs, language activity, language experience and/or language matrices of world interpretation. Hence, the network projects fall within the worldview, psychomotor, affective and/or cognitive domain.

To systematise the scope of the ERL network, four key areas were established when the project started in 2016:

1. Potential of Language for General Education

2. Language Activity of Children

3. Personal Experience of Language

4. Language Matrixes of Reality Interpretation

In order to make room for more academics to join the network, these key areas were later renamed:

1. Language Beliefs (formerly: Potential of Language for General Education)

2. Language Activity (formerly: Language Activity of Children)

3. Language Experience (formerly: Personal Experience of Language)

4. Language Matrixes (formerly: Language Matrixes of Reality Interpretation) 
Since the present project started before the key areas were renamed, the former area names will be used. The topic of this paper is mainly related to areas 1,2 , and 3 of the ERL network. Each ERL key area comes with a set of guiding research questions. For the present project, questions from almost every key area were relevant.

Area 1, Potential of Language for General Education, has the following guiding research questions:

1. What function of language is assigned by educational systems of different countries?

2. What approach to language do teachers of different nationalities represent?

3. To what extent is the teaching of the native language bound with that of the foreign one?

4. What approaches to language in education are taken across different cultures?

When it comes to the Polish students, questions 2 and 3 are most relevant in a broader perspective. So far, the ERL network has not conducted any formal comparison between teachers in different countries when it comes to approaches to language. This paper may serve as one example from Norway. As for question 3, this will be a topic in this paper since I, as the teacher under investigation, lack skills in the native language (Polish) of the students.

Area 2, Language Activity of Children, has the following guiding research questions:

1. How is children's language activity valued and assessed in educational systems of different countries?

2. What evidence is viewed in different countries as reasons for promoting pupils' language activity?

3. What hinders the development of pupils' language competence in different societies and cultures?

4. By what means is the language of children encouraged in particular countries? 
In the present study, the terms children and pupils must be replaced with students. All four questions are relevant in a broader perspective. However, again, there is no comparative study at the present stage and this paper has to be seen as a perspective from one institution and one country (Norway). Question 3 may be of special interest since different countries might have different pedagogical views on formal grammar learning and second language learning. All four questions from this area are relevant and interesting for future research, but I will only be able to touch on certain aspects of these questions in this study.

Area 3, Personal Experience of Language, has the following guiding research questions:

1. How do children of particular nationalities experience their contact with and use of language?

2. Which language skills are appreciated the most in different countries?

3. To what extent is the personal experience of language determined by social practices?

4. What differences can be observed in pupils' approach to their native and foreign languages?

Here, too, the terms children and pupils have been replaced with students. All four questions are relevant for the present study, even though I can only address certain aspects of them.

\section{Polish students studying Norwegian}

According to Wikipedia, there are more than 55 million native speakers of Polish (in 2010) and Poland has a rather large population (approximately 38 million in 2017). In comparison, Norway has a population of only a little more than 5 million and there are approximately 5 million native speakers of Norwegian (in 2014). In this respect, Norway is a rather small country and Norwegian is a rather small language compared to Polish. On Wikipedia's "List of Languages by number of native 
speakers", one finds Polish at number 30, Swedish at number 91 (approximately 8.7 million native speakers) and Norwegian is not on this list of 100 entries at all. Still, there are several universities in Poland that offer Scandinavian studies with Norwegian as one of the Scandinavian languages, and interest seems to be growing.

\section{Motivation}

Motivation is one of the key concepts in language learning and in learning in general (e.g. Dörneyi and Schmidt 2001; Lasagabaster, Doiz and Sierra 2014; Oxford 1996). As Laudari (2015: 1) puts it,

It [ = motivation] plays a significant role in a person's choices, actions, and persistence in an action. It indicates the 'direction and magnitude of human behavior' (Dörneyi, 2001a, p.8) and seeks to answer why people behave the way they do (Dörneyi, 2005, p.66). Motivation in learning an additional language plays an important role as it influences the desire to start learning the language, and the effort put to sustain this task of learning (Ellis, 1997; Ortega, 2009 , p. 168). So it is regarded to be the impetus to initiation to second language (L2) learning and the force to sustain it in its long and tedious process (Dörneyi, 2005; Pintrich \& Schunk, 1996).

Given the fact that Norway lies far to the north of Europe, a relevant question would be what motivation might Polish students have for studying Norwegian instead of, for instance, German. For students from Gdansk and especially Szczecin in the north of Poland, the most common answer from the students themselves is the contact with the Scandinavian countries on the other side of the Baltic Sea and the desire to work within the import/export field. The University of Szczecin offers language studies with a business component. There is also the common motivation connected to the general appeal of the country, the culture and the language itself from a more 
tourist-oriented perspective. Many students seem to be attracted by the wild nature of Norway or possibly by certain parts of Norwegian culture, like for instance the Viking heritage (boosted by modern TV series and movies) or Norwegian music genres. However, there is a major difference between those who actually move to Norway to work, like the thousands of craftsmen that come to Norway each year (according to Statistics Norway (2017), there are more than 100, 000 Polish people living in Norway in 2017), and those who embark on several years of academic studies directly after school to learn the Norwegian language with no more concrete plans beyond that.

Among the students in the present study, there seem to be few who show clear signs of increased learning efforts because of a genuine motivation to learn Norwegian. That being said, one has to keep in mind that learning about the language and culture of another country is different from attending academic courses in linguistics. From this perspective, the Polish students do not differ much from Norwegian grammar students. Generally, one could say that most students, both Norwegian and Polish, are not fond of learning formal grammar. Grammar studies are seen as "a necessary evil" in the curriculum. Hence, the motivation is accordingly low.

\section{Language teaching and grammar skills}

This paper is going to point at the importance of formal grammar skills in language education; with grammar skills meaning formal knowledge of phonology, morphology, syntax, semantic and pragmatics. Since grammar studies frequently do not have a high "status" among language students, the motivation for acquiring grammar skills is generally low and consequently many language teachers do not feel too competent in the field of formal grammar and, therefore, choose to focus on culture and literature in their teaching. 
Since most of the Norwegian students in the present study are student teachers who plan to have a future in teaching the Norwegian language in one way or the other, it is interesting to look at some areas where formal grammar skills are important.

\section{Slavic languages versus Germanic languages}

One challenge for Polish students studying Norwegian - or for a teacher who wants to teach Norwegian to students from Poland - is the difference between the two languages and their language families. Polish is a member of the Slavic language family with the respective phonological system and an augmented Latin alphabet with sounds and diacritic signs that are unfamiliar to a Norwegian. For instance, the initial consonant combination in the words Szczecin and Gdansk would not be possible in Norwegian. Norwegian, on the other hand, is a member of the Germanic language family and is closely related to languages such as German and English. The only Nordic letter augmentations which might cause difficulties for Polish students are $æ, \varnothing$, and $a$. Since most Polish students are already familiar with English and possibly German, Norwegian is not too difficult for them to access from that perspective. By comparison, it is uncommon in Norway to learn Slavic languages in school, even though some secondary schools offer Russian in addition to more "popular" languages like Spanish, French or German. Learning Polish would demand much more effort from a Norwegian student in comparison to a Polish student learning Norwegian after having learned English and possibly German. As a language teacher, one would need some general knowledge about language typology and the fact that Slavic languages and Germanic languages are different in certain respects. Furthermore, one would also need to be aware of the possibility of transfer from English and/or German in the language of their Polish students. When it comes to Norwegian, one needs to keep in mind that students might not be able to distinguish between the two written variants of Norwe- 
gian (Bokmål and Nynorsk, see e.g. Wardhaugh 2010: chap. 2) and the difference between oral speech, which is mostly dialect based, and official written language(s). However, it has not been possible to detect influences from oral speech in the present study. This is most likely due to the fact that the Polish students did not practise much Norwegian outside of the classroom.

As for Area 2 of the ERL network, Language Activity of Children [Students], question 3 would be relevant to ask: "What hinders the development of pupils' [students'] language competence in different societies and cultures?" For the Polish students in Poland, Norwegian would be a foreign language and learning it would mostly be a classroom activity. Norwegian would not be used outside of the classroom, and the language is not necessary in Polish society. For the Polish students in Norway, Norwegian would, potentially, be a second language from a learning perspective. Even though the students would meet Norwegian grammar in the classroom, the language is also used in most domains outside of the classroom and it would be expected to be necessary almost everywhere. However, there are some relevant questions to be asked about both learning situations. Most teachers of Norwegian in Poland are Polish, i.e. they are not native speakers of Norwegian, which might be a question of quality in some cases. Another aspect would be that it turns out to be rather difficult to get access to learning material in Norwegian. But that is more of a structural problem. As for the learning situation in Norway, one might ask to what extent the students actually are part of Norwegian society while they are on exchange. Quite often, they live in student homes together with other foreign students and they actually speak Polish or English outside of the classroom rather than Norwegian. This should be expected. Aside from the fact that the students normally need to pass their examination(s) in Norwegian, Norwegian is not necessarily something the students actually need during their stay in Norway since it is not a problem to use English in most contexts. This means 
that the learning situation is not entirely optimal from a practical and motivational perspective.

As for Area 1 of the ERL network, Potential of Language for General Education, the following guiding research questions are relevant to ask when it comes to the Polish students of Norwegian: "What approach to language do teachers of different nationalities represent? To what extent is the teaching of the native language bound with that of the foreign one? And what approaches to language in education are taken across different cultures?

It is not possible to say anything general about the approach of different nationalities. But from the perspective of a Norwegian language teacher trying to teach Norwegian to Polish students and to Norwegian student teachers who potentially might teach foreign students in the future, it is only natural to have a contrastive approach to language teaching.

\section{Contrastive analysis and transfer}

This is not the place to discuss contrastive analysis, based on Lado (1957), in general. As a language teacher, one would be interested in the practical and didactic aspects of contrastive analysis and transfer. In the present paper, the intention is to show that general linguistic knowledge and skills are important for teachers in order to understand errors and help language students.

Having very poor knowledge of Polish, how would one approach certain aspects of the language as a language teacher and language learner? Take the word Szczecin. From a Norwegian point of view, the combination of the four consonants in the beginning of the word is impossible to pronounce. The four letters as a whole are an impossible combination, and there is no $<$ sz $>,<\mathrm{zC}>$ nor $<\mathrm{CZ}>$ in Norwegian either. In fact, the letters $<c>$ and $\langle z>$ are only used in certain names and loanwords. Now, as a language teacher, one is supposed to have knowledge of general linguistics, including phonology, i.e. the 
part of grammar that deals with how the sounds of a given language are part of a grammatical system. One would also know that neither Norwegian, English nor German have a single letter that in all cases represents the sound and potential phoneme [S]. In Norwegian, there are different letters and combinations of letters that may represent this phoneme/sound, e.g. <sk> in ski ('ski'), <skj> in skje ('happen'), <sj> in sjel ('soul'), $<$ s $>$ when preceding $<1>$ as in Oslo (the capital) or $<$ s $>$ when following $<\mathrm{r}>$ as in Lars (the name 'Lars'). In English and German, the most common combination of letters to represent the sound and potential phoneme [J] would be $<$ sh $>$ as in shine and $<$ sch $>$ as in Schein. Based on this knowledge, one might start with the hypothesis that the four letters in the word Szczecin only represent two phonemes in Polish. This alone is a huge help for a language teacher (and learner). Some teachers might also know German and the German name for the town Szczecin, Stettin. Seeing these two names side by side makes it easier to hypothesize that we are most likely dealing with two phonemes in the beginning of the word. It also helps to know that the combination of $\langle\mathrm{s}\rangle$ and $\langle\mathrm{t}\rangle$ would be pronounced [ $\mathrm{ft}$ ] in German in the initial position of a word (it would be [st] in Norwegian). All this does not mean that the hypotheses are actually $100 \%$ right, but it would certainly help a lot when trying to understand the language system of another language. As for the word Szczecin, it seems that the pronunciation is actually [ $\left[\mathrm{t} \int\right]$. Learning this, one would now be able to work on one's own understanding of the differences between Norwegian and Polish. Looking for similar words in Norwegian and Polish, for instance, <sjal> versus <szal> ('scarf'), one would soon find out that these two words indeed match each other very well when it comes to the representation of the sound [J]. And, when checking the Italian loanword $<$ cello $>$ [t $\left.\int e l l o\right]$, which usually is pronounced [fello] in Norwegian, one would find that Polish has the longer version <wiolonczela $>$, with the combination $<\mathrm{cz}>$ for [t $\mathrm{t}]$. Apparently, con- 
trastive analysis and the potential of transfer might be helpful for the language teacher and learner.

As a language teacher and as a language learner, one would also benefit from having some general knowledge of syntax and the syntactic differences between Norwegian and Polish. A typical problem for learners of Norwegian as a foreign or second language is related to the fact that Norwegian is a verb second (V2) language. This means that the finite verb (present tense or past tense) has to be located in the second position in main sentences. To understand this, one would also need to know about phrases or constituents. Since the V2 rule is a rather strict rule with few exceptions one would think it would be easy to remember and easy to use. Still, most learners of Norwegian struggle with placing the verb in the right position. As a language teacher, one would need to know how to help one's students. The "problem" arises, for instance when there is a time adverbial in the sentence, as in:

$\begin{array}{lllll}\text { (1) Idag skal vi lære litt } & \text { om } \\ \text { today } & \text { shall we learn } & \text { (a) little } & \text { about } \\ \text { norsk } & \text { syntaks. } & & \\ \text { Norwegian } & \text { syntax } & & \end{array}$

As a language teacher and learner, one would need to be able to understand that the first two words ( $i$ dag) belong to the same phrase and constituent and therefore have to occupy only one space in the sentence. The finite verb (skal) is, therefore, correctly placed in the second position (V2). Now, German is also a V2-language, when it comes to main clauses, e.g.:

$\begin{array}{lllll}\text { (2) Heute wollen wir ein bisschen über norwegische } \\ \text { today shall we a little } & \text { about Norwegian } \\ \text { Syntax } & \text { lernen. } & & & \\ \text { syntax learn } & & & \end{array}$

Interestingly, German learners of Norwegian make the same word order mistakes when it comes to the V2-rule as Polish 
learners. The obvious reason would be that both groups of learners struggle with transfer from another foreign/second language they have learned before and that they are exposed to more frequently, namely English. English, however, is not a V2-language:

(3) Today we shall learn a little about Norwegian syntax.

Consequently, both German and Polish learners of Norwegian quite often produce the following word order in Norwegian sentences (which we now know is incorrect):

$\begin{array}{lllll}\text { (4) }{ }^{*} \text { Idag vi } & \text { skal lære litt } & \text { om } \\ \text { today we } & \text { shall learn } & \text { (a) little } & \text { about } \\ \text { norsk } & \text { syntaks. } & & \\ \text { Norwegian } & \text { syntax }\end{array}$

When trying to analyse different word order mistakes made by my Polish students, one student in the present study argued that Polish is a so-called free word order language. He actually claimed that all single words could in principle be placed anywhere in a sentence. Even with no prior knowledge of Polish, one should doubt the student's statement on theoretical grounds. Real free word order would be counterintuitive since there at least should be constraints when it comes to constituents and information structure. A deeper discussion about Polish grammar was, however, not possible with that student. In general, it may seem that most students know little about the formal grammar of their own language and lack basic knowledge of common grammatical terms like inflection, word classes, sentence constituents and functions. According to the Polish Language Blog (2011): "Basic word order in Polish is SVO, however, as it is a morpheme rich language, it is possible to move words around in the sentence, and to drop the subject, object or even sometimes verb, if they are obvious from context". Apparently, Polish has the same basic word order as Norwegian and English (and German in main clauses), i.e. 
subject - verb - object (SVO). Language blogger Kasia also provided some examples (Polish Language Blog 2011):

These sentences mean more or less the same ("Kasia has a cat"), but different shades of meaning are emphasized by selecting different word orders:

Kasia ma kota - Kasia has a cat (when spoken with a different sentence tempo and accentuation, this sentence can be understood as mildly offensive idiom "Kasia is crazy" or "Kasia is a loony").

Kasia kota ma - Kasia does have (own) a cat (and has not borrowed it)

Kota ma Kasia - The/a cat is owned by Kasia

Ma Kasia kota - Kasia really does have a cat

Kota Kasia ma - It is just the cat that Kasia really has

Ma kota Kasia - The relationship of Kasia to the cat is one of ownership (and not temporary possession)

However, only the first three examples sound natural in Polish, and others should be used for special emphasis only, if at all.

As interesting as these examples might be, they are made up of single word phrases. Therefore, it is not that easy to see the full potential of possible free word order. Checking Wikipedia for further information on Polish grammar, one would find that

The grammar of the Polish language is characterized by a high degree of inflection, and has relatively free word order, although the dominant arrangement is subject-verb-object (SVO). There are no articles, and there is frequent dropping of subject pronouns. Distinctive features include the different treatment of masculine personal nouns in the plural, and the complex grammar of numerals and quantifiers.

Acquiring a minimum of knowledge of the grammar of the students' mother tongue would help the teacher in giving them better guidance. 


\section{Data and discussion: \\ Error examples from student examinations}

We will now look at some examples of errors from student examinations and try to analyse them.

(5) De mest kjent reformer var i 1900-tallet og de mest kjent språkdebater var i 1800-tallet.

'The most known (language) reforms happened in the 20th century and the most known language debates happened in the 19th century.'

Here, the field of grammar which a language teacher needs to have knowledge of is morphology. The student has no problem with keeping the words of the constituents <de mest kjent reformer $>$ and <de mest kjent språkdebater $>$ together, but there is an agreement problem since <kjent> is supposed to be inflected in the plural form: <kjente $>$. A teacher should point out that it is more common to use the so-called double definite form in Norwegian, i.e. < de ... reformene $>$ and $<$ de ... debattene>. The student has also chosen the wrong preposition in front of the word for centuries (tallet). While English (and German) would use <in> before the corresponding time expressions, Norwegian would have "on", i.e. <på>. Actually, Norwegian differentiates between the use of prepositions $(<i$ $1813>$ vs. <på 1800-talet> ('in 1814 vs. in the 18 hundreds')). The last error in this example has to do with phonology and orthography. The student writes $<$ debater $>$ instead of $<$ debatter $>$ with two t's. Since the corresponding word is $<$ debata $>$ in Polish and <debate> in English, this error is most likely due to transfer from the mother tongue or English. However, a teacher of Norwegian would also inform the student about the spelling rule in Norwegian that states that double consonants are used to mark short vowels. Even though there are many exceptions to this rule in Norwegian, this rule could be useful for the student. 
Another example is the following:

(6) Vi har mange reformene har. 'We have many reforms here.'

One problem in this sentence is the wrong use of the definite form of the noun <reformene>, which should have the indefinite form <reformer $>$ in this case. The double definite form of nouns in Norwegian is a challenge for many foreigners, but for a language teacher, the wrong spelling of $<$ har $>$, which should be $<$ her $>$, is more interesting. In order to understand this mistake one would need to have knowledge of phonology. While English has the spelling <here> and the pronunciation [hi:r], Norwegian has the spelling <her $>$ and the pronunciation [hæ:r]. Apparently, the Polish student had some trouble distinguishing the low front vowel [æ] from [a]. Consequently, the teacher should suggest a study of the Norwegian vowel system and special training in distinguishing difficult vowels (for instance also the Norwegian vowel $[y]$ versus $[\mathfrak{u}])$.

In the following example:

(7) ... i landsbygda utviklet seg forskjellig norske dialekter... '... in the countryside different dialects developed ...'

the student chose the wrong Norwegian preposition $(<\mathrm{i}>$ instead of $\langle$ på $>$ ) and missed the plural ending in $<$ forskjellig[e] $>$. In many instances, the use of prepositions has to be learned from case to case and can even vary. The more interesting error in this sentence, however, is the lack of the formal subject <det> ('it'). So, in order to be able to help this student the teacher would need to have knowledge of Norwegian syntax. The Polish language seems to lack a formal or expletive subject. Therefore, the teacher would have to explain the concept of a formal subject and would need to know ways of showing why and where the expletive subject is supposed to appear (directly behind the finite verb or in first position). 
The next example is related to the field of phonology:

(8) ... offisjelle skriftlige versjoner ... 'official written versions'

The Norwegian spelling of 'official' is (here the plural form) <offisielle $>$ and the pronunciation would be [ofisi'elə]. One might think that there could be an (orthographic) transfer from the correctly spelled word <versjoner> ('versions') in the same phrase with $<$ sj $>$ for the sound [J], but that does not match the Norwegian pronunciation. For the teacher, it would help to know that the Polish spellings exhibit $a<j>$ in both cases: $<$ oficjalna wersja>. However, the Polish pronunciation of the same phrase is not that distant from the Norwegian pronunciation. Thus, the $\langle j>$ would be the only sign that the transfer could come from Polish itself. Instead, the error may originate in a transfer from English pronunciation, where we, despite the different spellings, find the [J] sound in both words: <official versions $>$.

Another example is from syntax, i.e. constituent order:

(9) ... å bringe nærmere begge språkene til hverandre '... to bring closer both languages to each other'

Instead of just telling the students that this would not be a possible word/constituent order in Norwegian (or English), even though it might work in Polish, the teacher should explain that Norwegian is not only an SVO language, but that it would, in fact, be SVOA, i.e. subject - verb - object - adverbial. The phrase <nærmere> ('closer') being an adverbial can therefore not precede the object <begge språkene> ('both languages').

The last example in the present study is most likely related to semantics and lexicon: 
(10) Jeg skal neune om begreper språkpolitikk og språknormering som er knyttet med dette temaet

'I will name/mention (/talk about) the concepts language policy and language standardization that are tied to this topic'

Here, it is actually not easy to find out what might have caused the student to make the first error $(<$ nevne om begreper $>$ ('mention/discuss concepts)), but the second error $(<$ knyttet med $>$ ('tied/connected to')) is easier to understand. In the latter, the right preposition would have been <til> ('to'). Both relevant English expressions, 'connected to' and 'tied to', would have the preposition <to>, which we would think would lead the student to choose Norwegian <til>. When the student chose the preposition <med> ('with'), a hypothesis would be that the Polish preposition $\langle z>$ could correspond to different prepositions in other languages and that the student just chose a random preposition. It might also be interesting to look at the fact that the verb <knytte $>$ ('tie/connect') would look rather unfamiliar for a student with English as a potential reference language. The corresponding linguistic relative would be 'knit'. Semantically, we can see how 'knit together' is related to 'tie together/to' or 'connect to'. In the same semantic field, we would find 'associated with', with the preposition <with>, which would correspond to Norwegian <med $>$. Here, however, it seems that the transfer comes from Polish, which, in its turn, should make the language teacher want to acquire some basic knowledge of the grammar system of the students' first language. As for the error <nevne om>, one may suspect that there must be some semantic and syntactic transfer, too. But, we observe again that the student does not choose the obvious solution via looking at English. The verb $<$ name $>$ does not take a preposition in English (either), nor do the other relevant verbs in this context, <mention> or <discuss >. A hypothesis would be that the student does not have a full understanding of the verb <nevne> ('name'>) and that it might be used with the meaning 'talk/write about' in this sentence. The corresponding Norwegian expressions would be <snakke/skrive 
om>. Hence, the preposition <om> ('about'). General knowledge of grammar and error analysis, thus, would be of great help when trying to guide language students.

A meta comment from a student's examination paper about the topic of multilingualism may serve to conclude the discussion on error analysis and transfer:

(11) For eksempel: jeg er utvekslingstudent fra Polen. Det er mange polske studenter som er med. Hvis jeg snakker med dem, trenger jeg ikke å bruke et annet språk enn polsk (det er jo ikke flerspråklighet), men hvis jeg snakker med nordmenn eller andre personer som er på erasmus (på forelesning eller felles kjøkkenet) bruker jeg norsk eller engelsk (det er flerspråklighet).

'For instance: I am an exchange student from Poland. There are many (other) students there. When I talk to them I don't need another language than Polish (that's not multilingualism). But when I talk to Norwegians or other people who are on Erasmus (exchange) (during lectures or in the common kitchen), I use Norwegian or English (that's multilingualism).'

This illustrates the learning conditions for exchange students and shows how some of them mainly use Polish outside of the classroom. Norwegian may often be the last choice after English. Hence, transfer from Polish and English may happen on a regular basis.

\section{Conclusions}

This paper has tried to emphasize the importance of grammar knowledge for both language teachers and students. At the same time, it is a contribution to the work of the ERL network when touching on some of the key areas and their guiding questions. 


\section{ERL network area 1, Potential of Language for General Ed- ucation:}

1. What function of language is assigned by educational systems of different countries?

2. What approach to language do teachers of different nationalities represent?

3. To what extent is the teaching of the native language bound with that of the foreign one?

4. What approaches to language in education are taken across different cultures?

Since the case is about teachers of Norwegian grammar in higher education (college/university level), one also has to deal with the Norwegian educational system in general. At college/university level, a language study is most often more or less equally divided into grammar and literature (and possibly culture) with separate grades and study credits. In primary and secondary school, however, there has been more focus on practical skills when it comes to language use rather than theoretical skills in grammar. Hence, pupils and students usually have relatively little knowledge of formal grammar when starting on a language study. One might say that the Norwegian educational system seems to emphasize speaking and understanding in general instead of speaking and writing as grammatically correctly as possible. The function of grammar in teaching and learning might be under-communicated. This also impacts teacher education and teachers. With less grammatical knowledge from school and teacher education, younger teachers often have even less focus on grammar; thus, they become a part of a vicious cycle. As for question 3, on the other hand, many teachers are able to contrast teaching of the mother tongue with another language, preferably English. Teaching Norwegian to Polish students benefits from contrasting with English and possibly Polish, given that the teacher has some basic understanding of Polish grammar. As for question 4 , it was already mentioned that literature and cul- 
ture seem to have gained ground when it comes to the functional approach to language learning. This paper attempted to point out that a contrastive approach with error analysis should find its way back into the classroom.

\section{ERL network area 2, Language Activity of Children [stu- dents]:}

1. How is children's language activity valued and assessed in educational systems of different countries?

2. What evidence is viewed in different countries as reasons for promoting pupils' language activity?

3. What hinders the development of pupils' language competence in different societies and cultures?

4. By what means is the language of children encouraged in particular countries?

When it comes to language studies at the college/university level, grammar disciplines are usually valued and assessed on their own terms. However, many students seem to underestimate the value and importance of grammar, regarding it more as a necessary evil without actually seeing the point to it. One reason might be the fact that grammar has less focus in previous education with emphasis placed on average communication skills. Another reason could be that language education on college and university level is very traditional with a $19^{\text {th }}$ century perspective on grammar as being a discipline in its own right. Since most language students end up in the educational system in one way or the other, it would be important to focus on the didactic perspectives of language teaching also when teaching grammar. As for the questions 2 and 4 of this area, in Norway there has been a tendency to choose Spanish as a second foreign language (after English, which is mandatory for all pupils). Traditional languages like German and French have lost ground in secondary schools in Norway and consequently at the college and university level since recruiting fails. Even though Germany is Norway's most important 
trade partner and one would think that pupils and students would try to get an advantage in future working life by learning German, pupils (and parents) would often choose Spanish because they go to Spain on vacation. Learning a foreign language other than English, then, is first of all connected to pleasure and not to professional benefits. Governmental attempts to promote German and French have not been very successful. As for the Polish students studying Norwegian at the university level, there is obviously a practical motivation in most cases, since many of the students seek jobs within the import/export domain. However, there seem to be quite a few students who just happen to like the country and the culture. As for question 3, Polish exchange students are often hindered or slowed down in their language learning by the fact that they stick together with other Polish students or other international students which causes them to use Polish or English in their time outside the classroom.

\section{ERL network area 3, Personal Experience of Language:}

1. How do children of particular nationalities experience their contact with and use of language?

2. Which language skills are appreciated the most in different countries?

3. To what extent is the personal experience of language determined by social practices?

4. What differences can be observed in pupils' approach to their native and foreign languages?

There is nothing to say about question 1 in the present discussion. As for question 2 , it has already been mentioned that one has a functional approach in Norway with a focus on oral / communicative skills while grammar skills usually are seen as a necessary evil, not only by the pupils/students but also by the teachers. When it comes to question 3 , the perspective has been on teaching and learning grammar in this study. Neither foreign students, like the Polish, nor 
Norwegian students have much personal experience with grammar. In the formal study of Norwegian, grammar is an educational discipline that is assessed and credited with official papers. The Polish students struggle with acquiring grammatical rules in order to learn Norwegian, while the Norwegian students struggle with acquiring rules in order to be able to explain them. Neither group seems to make a great effort to include grammar in social practices like in study groups. Even when with other international students who need to learn Norwegian, most students choose English to communicate outside of the classroom. As for question 4, the Norwegian students already know how to speak and write Norwegian more or less correctly. Hence, they have difficulties understanding the need for formal grammar knowledge about their own language, which is rather unfortunate if they are planning a career as a language teacher. The Polish students frequently have poor formal knowledge about the grammar of their own language and they struggle with all the aspects of learning the Norwegian language, literature, and culture. Grammar being the least accessible part of their studies, and requiring more effort than just understanding the words and the meaning, is usually unpopular and many students postpone and reduce grammar studies to a minimum. They have this attitude in common with the Norwegian students.

In the present study, it has been shown that most students are not very motivated to study grammar and that the school system does not support grammar studies very much, either. Nevertheless, it is obvious that grammar skills are important for teachers and learners. As for the level of grammar skills, language teachers should have good grammar skills in the target language and some general linguistic knowledge in order to help their students understand and learn the language. Language teacher education should have a special focus on language didactics. 


\section{References}

Dörneyi, Z. (2001). Teaching and Researching Motivation. Harlow, UK: Pearson Education Limited.

Dörneyi, Z. (2005). The Psychology of the Language Learner: Individual Differences in Second Language Acquisition. USA: Lawrence Erlbaum Associates.

Dörney, Z., R. Schmidt (eds.) (2001). Motivation and Second Language Acquisition. Technical report \#23. Second Language Teaching \& Curriculum Center. Hawai'i: University of Hawai'i at Mãnoa.

Ellis, R. (1997). Second Language Acquisition Research and Language Teaching. Oxford: Oxford University Press.

ERL 2 2017. Available at <http://www.educationalroleoflanguage. ug.edu.pl/2nd-conf-programme>. Accessed 12.09.2017.

ERL Network (2017). Available at <http://educationalroleoflangu age.ug.edu.pl/erl-network-0>. Accessed 12.09.2017.

Lado, R. (1957). Linguistics across Cultures. Ann Arbor: University of Michigan Press.

Lasabagaster, D., A. Dois, J. M. Sierre (eds.) (2014). Motivation and Foreign Language Learning: From Theory to Practice. Amsterdam Philadelphia: John Benjamins Publishing Company.

Laudari, S. (2015). Motivation in Learning a Second Language. Saarbrücken: Lambert Academic Publishing.

Ortega, L. (2009). Understanding Second Language Acquisition. UK: Hodder Education.

Oxford, R. L. (ed.) (1996). Language Learning Motivation: Pathways to the New Century. Technical report \#11. Second Language Teaching \& Curriculum Center. Hawai'i: University of Hawai'i at Mãnoa.

Pintrich, P. R., D. H. Schunk (1996). Motivation in Education: Theory, Research and Applications. Englewood Cliffs, NJ: Prentice Hall.

Polish Language Blog (2011). Available at <http://blogs.transparent. $\mathrm{com} /$ polish/word-order-in-polish-grammar/>. Accessed 16.09.2017.

Statistics Norway (2017). Foreign citizens by citizenship and sex. 1 January. Available at <https://www.ssb.no/en/befolkning/ statistikker/folkemengde/aar-per-1-januar>. Accessed 16.09.2017.

Wardhaug, Ronald (2010). An Introduction to Sociolinguistics. Sixth edition. West Sussex: Wiley-Blackwell.

Wikipedia: List of Languages by number of native speakers. Available at <https://en.wikipedia.org/wiki/List_of_languages_by_number_ of_native_speakers>. Accessed 16.09.2017. 
Wikipedia: Norway. Accessed at: <https://en.wikipedia.org/wiki/ Norway>. Accessed 16.09.2017.

Wikipedia: Norwegian. Available at <https://en.wikipedia.org/wiki/ Norwegian_language $>$. Accessed 16.09.2017.

Wikipedia: Poland. Available at <https://en.wikipedia.org/wiki/ Poland. Accessed 16.09.2017.

Wikipedia: Polish grammar. Available at <https://en.wikipedia.org/ wiki/Polish_grammar>. Accessed 16.09.2017.

Wikipedia: Polish language. Available at <https://en.wikipedia.org/ wiki/Polish_language>. Accessed 16.09.2017.

Jens Haugan

ORCID iD: 0000-0001-9708-2038

Inland Norway University of Applied Sciences

Campus Hamar

2318 Hamar

Norway

jens.haugan@inn.no 